\title{
Mortality in punctiform type of coalworkers' pneumoconiosis
}

\author{
W. E. WATERS ${ }^{1}$, A. L. COCHRANE, and F. MOORE \\ Medical Research Council's Epidemiology Unit (South Wales), Cardiff
}

\begin{abstract}
Waters, W. E., Cochrane, A. L., and Moore, F. (1974). British Journal of Industrial Medicine, 31, 196-200. Mortality in punctiform type of coalworkers' pneumoconiosis. Recent studies conducted on miners at necropsy and on those attending a pneumoconiosis medical panel have suggested that the punctiform type of opacities are associated with a significant gas transfer defect and with emphysema. However, a 10-year follow-up of a random sample of miners and ex-miners in the Rhondda Fach found that the mortality experience of those with the punctiform type was, if anything, more favourable than that for other types of pneumoconiosis. This may be related to radiographic technique, but there may also be physiological reasons. There was no evidence that those with the punctiform type had different smoking habits from those with other types of pneumoconiosis.
\end{abstract}

The radiological classification of simple pneumoconiosis (International Labour Office, 1959) divides films into three categories $(1,2$, and 3$)$ on the basis of the number, and into three types on the basis of the size, of the opacities. The types are defined according to the greatest diameter of the predominant opacities; punctiform opacities (p) are defined as up to $1.5 \mathrm{~mm}$. The proportion of all cases of simple pneumoconiosis that are read as punctiform shows some observer variation, but many observers record about $10 \%$ of cases as having punctiform opacities (Fletcher, 1955), although more recently a higher percentage of these opacities are often being recorded. The classification according to the type of the predominant opacities has until recently received less attention than that into the category. This is because the follow-up of cases with simple pneumoconiosis has shown that progression is mainly related to the category rather than to the type of opacity (Davies, Fletcher, Mann, and Stewart, 1950). However, a study of miners attending a pneumoconiosis medical panel has found a significant gas transfer

\footnotetext{
1 Present address: Senior Lecturer in Clinical Epidemiology and Community Medicine, South Block, Southampton General Hospital, Southampton SO9 4XY
}

defect in men with punctiform opacities compared with those having micronodular opacities (Lyons, Clarke, Hall, and Cotes, 1967). Also, in a population coming to necropsy, it was found that cases with punctiform markings showed a higher excess of emphysema than those with the micronodular and nodular types (Ryder, Lyons, Campbell, and Gough, 1970). Lapp and Seaton (1971) found a reduced. single-breath diffusing capacity in American miners with $\mathrm{p}$ type simple pneumoconiosis.

This paper reports the mortality experience of a community sample seen 10 years previously.
Method
In 1958 a stratified random sample of 300 miners and ex-miners aged between 35 and 64 years was drawn after a private census in the Rhondda Fach in Glamorgan (Higgins and Cochrane, 1961) and 275 of these had a chest radiograph. These were read for category of pneumoconiosis and those with category $1 / 2$ or more on the extended classification of the International Labour Office (1970) were read for type. (This extended classi- fication subdivides category 1 simple pneumoconiosis into $1 / 0,1 / 1$, and $1 / 2$ with increasing profusion of small opacities; category $1 / 2$ is the lowest category where type 
-micronodular, nodular, punctiform-was read.) An assessment of the quality of the radiographic technique was also made. Smoking habits were recorded at the same time. These men, and 262 respondents of a random sample of 300 non-miners from the same area and seen in the original survey, were followed up in 1968.

\section{Results}

The follow-up was complete in that copies of death certificates were obtained for all men seen in the 1958 survey who were not known to be alive in 1968. The death rate by category of pneumoconiosis is shown in Table 1. The death rate for those with simple pneumoconiosis and early progressive massive fibrosis (PMF) was not higher than for miners without pneumoconiosis, but the mortality for all miners was higher than that of the non-miners living in the same area. It is suggested that the difference might be due in part to selective migration.

Of the 98 miners and ex-miners with pneumoconiosis of category $1 / 2$ or more and where type was readable in 1958, 19 were read as punctiform. Only one of these men had died during the 10-year period. The expected number of deaths among those with punctiform markings, assuming their mortality experience to be the same as for all those with pneumoconiosis readable for type, is 3.40 (Table 2). This finding raised the possibility that there might be some cross-correlation between 'punctiform' and mortality which affected the results. One possibility was technique. Table 3 shows the numbers of deaths in each type and category of pneumoconiosis by the

TABLE 1

Death Rates for Miners and Ex-miners, by Pneumoconiosis Category, AND FOR NON-MINERS, 1958-68

\begin{tabular}{|c|c|c|c|c|c|c|c|c|c|c|c|}
\hline \multirow{3}{*}{\multicolumn{3}{|c|}{ Category (in 1958) }} & \multicolumn{9}{|c|}{ Age (years) in 1958} \\
\hline & & & \multicolumn{3}{|c|}{$35-44$} & \multicolumn{3}{|c|}{$45-54$} & \multicolumn{3}{|c|}{$55-64$} \\
\hline & & & $\begin{array}{c}\text { No. seen } \\
1958\end{array}$ & $\begin{array}{c}\text { No. dead } \\
1968\end{array}$ & $\%$ & $\begin{array}{c}\text { No. seen } \\
1958\end{array}$ & $\begin{array}{c}\text { No. dead } \\
1968\end{array}$ & $\%$ & $\begin{array}{c}\text { No. seen } \\
1958\end{array}$ & $\begin{array}{c}\text { No. dead } \\
1968\end{array}$ & $\%$ \\
\hline $\begin{array}{l}0 \\
1,2,3,\end{array}$ & & $\begin{array}{l}\cdots \\
\cdots \\
\cdots\end{array}$ & $\begin{array}{r}36 \\
46 \\
4\end{array}$ & $\begin{array}{l}2 \\
2 \\
2\end{array}$ & $\begin{array}{r}5 \cdot 6 \\
4 \cdot 3 \\
50 \cdot 0\end{array}$ & $\begin{array}{l}27 \\
55 \\
13\end{array}$ & $\begin{array}{r}5 \\
12 \\
5\end{array}$ & $\begin{array}{l}18 \cdot 5 \\
21 \cdot 8 \\
38 \cdot 5\end{array}$ & $\begin{array}{l}25 \\
59 \\
10\end{array}$ & $\begin{array}{r}12 \\
18 \\
4\end{array}$ & $\begin{array}{l}48 \cdot 0 \\
30 \cdot 5 \\
40 \cdot 0\end{array}$ \\
\hline \multicolumn{3}{|c|}{ All miners and ex-miners } & 86 & 6 & $7 \cdot 0$ & 95 & 22 & $23 \cdot 2$ & 94 & 34 & $36 \cdot 2$ \\
\hline Non-miners & $\cdots$ & .. & 88 & 3 & $3 \cdot 4$ & 88 & 13 & $14 \cdot 9$ & 86 & 25 & $29 \cdot 1$ \\
\hline
\end{tabular}

TABLE 2

Expected and Observed Deaths for those with Punctiform Type Pneumoconiosis Where TyPe of PNeUmoconiosis WAS ReAD

\begin{tabular}{|c|c|c|c|c|c|c|c|}
\hline \multirow{3}{*}{$\begin{array}{c}\text { Age group } \\
\text { (in 1958) }\end{array}$} & \multirow{3}{*}{ Category } & \multicolumn{2}{|c|}{ Populations } & \multicolumn{4}{|c|}{ Deaths 1958-68 } \\
\hline & & \multirow{2}{*}{ Total } & \multirow{2}{*}{ Punctiform } & \multirow{2}{*}{ Total } & \multicolumn{3}{|c|}{ Punctiform } \\
\hline & & & & & Observed & Expected & \\
\hline $35-44$ & $\begin{array}{l}1 / 2,2 \text { or } 3 \\
\mathrm{~A} \\
\mathrm{~B} \text { or } \mathrm{C}\end{array}$ & $\begin{array}{r}15 \\
4 \\
2\end{array}$ & $\begin{array}{r}4 \\
1 \\
-\end{array}$ & $\frac{1}{-}$ & - & $\begin{array}{c}0.27 \\
0.00 \\
-\end{array}$ & $0 \cdot 27$ \\
\hline $45-54$ & $\begin{array}{l}1 / 2,2 \text { or } 3 \\
A \\
B \text { or } C\end{array}$ & $\begin{array}{r}19 \\
18 \\
6\end{array}$ & $\begin{array}{l}5 \\
3 \\
2\end{array}$ & $\begin{array}{l}5 \\
5 \\
-\end{array}$ & $\frac{1}{1}$ & $\begin{array}{c}1.32 \\
0.83 \\
-\end{array}$ & $2 \cdot 15$ \\
\hline $55-64$ & $\begin{array}{l}1 / 2,2 \text { or } 3 \\
\mathrm{~A} \\
\mathrm{~B} \text { or } \mathrm{C}\end{array}$ & $\begin{array}{r}13 \\
12 \\
9\end{array}$ & $\frac{2}{2}$ & $\begin{array}{l}2 \\
4 \\
3\end{array}$ & - & $\frac{0.31}{0.67}$ & 0.98 \\
\hline
\end{tabular}

Total observed deaths among those with punctiform type $=1$

Total expected deaths among those with punctiform type $=3.4$ 
TABLE 3

Radiographic Acceptability of Categories of Simple Pneumoconiosis 1/2, 2, and 3 AND PMF Where Type of PNeumoconiosis was Read (Ages 35-64 Years)

\begin{tabular}{|c|c|c|c|c|c|c|c|c|c|c|}
\hline \multirow{4}{*}{ Category } & \multicolumn{5}{|c|}{ Type micronodular or nodular } & \multicolumn{5}{|c|}{ Type punctiform } \\
\hline & \multirow{3}{*}{ No. } & \multicolumn{4}{|c|}{ Technique } & \multirow{3}{*}{ No. } & \multicolumn{4}{|c|}{ Technique } \\
\hline & & \multicolumn{2}{|c|}{ Acceptable } & \multicolumn{2}{|c|}{ Poor } & & \multicolumn{2}{|c|}{ Acceptable } & \multicolumn{2}{|c|}{ Poor } \\
\hline & & No. & Dead & No. & Dead & & No. & Dead & No. & Dead \\
\hline $\begin{array}{l}1 / 2,2 \text { or } 3 \\
A \\
B \text { or } C\end{array}$ & $\begin{array}{l}36 \\
30 \\
13\end{array}$ & $\begin{array}{l}31 \\
28 \\
12\end{array}$ & $\begin{array}{l}7 \\
7 \\
2\end{array}$ & $\begin{array}{l}5 \\
2 \\
1\end{array}$ & $\begin{array}{l}1 \\
1 \\
1\end{array}$ & $\begin{array}{r}11 \\
4 \\
4\end{array}$ & $\begin{array}{r}11 \\
4 \\
4\end{array}$ & $\frac{1}{-}$ & - & - \\
\hline Total & 79 & 71 & 16 & 8 & 3 & 19 & 19 & 1 & - & - \\
\hline
\end{tabular}

technical quality of the $1958 x$-ray films. Of the 79 micronodular or nodular type films, eight $(10 \%)$ were read as technically poor: of these, three men $(38 \%)$ had died, whereas of the 19 punctiform films none was read as technically poor. It would be reasonable to assume that technically acceptable films are obtained more frequently on fitter subjects. However, there may be physiological differences as the lung function in those with punctiform opacities, as judged by the 0.75 second forced expiratory volume $\left(\mathrm{FEV}_{0.75}\right)$, seems somewhat better than for those with other types of opacity. Although the numbers are small the differences are fairly consistent (Table 4). The relation between the type of simple pneumoconiosis and lung function is reviewed by Cotes, Deivanayagam, Field, and Billiet (1971).

Smoking habits are shown in Table 5. This was not recorded for two subjects. Of 78 men with

TABLE 4

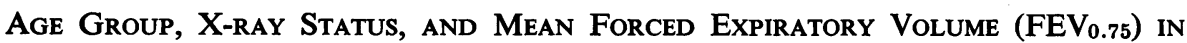
1958 OF THOSE IN WHOM TYPE OF PNEUMOCONIOSIS WAS READ

\begin{tabular}{|c|c|c|c|c|c|}
\hline \multirow{2}{*}{$\begin{array}{c}\text { Age } \\
\text { group } \\
\text { (in 1958) }\end{array}$} & \multirow{2}{*}{ Category } & \multicolumn{2}{|c|}{ Type micronodular or nodular } & \multicolumn{2}{|c|}{ Type punctiform } \\
\hline & & No. & $\begin{array}{c}\text { Average FEV } \\
\quad \text { (litres) }\end{array}$ & No. & $\begin{array}{c}\text { Average FEV } \\
\text { (litres) }\end{array}$ \\
\hline \multirow[t]{2}{*}{$35-44$} & $\begin{array}{l}1 / 2,2 \text { or } 3 \\
\mathrm{~A} \\
\mathrm{~B} \text { or } \mathrm{C}\end{array}$ & $\begin{array}{r}11 \\
3 \\
2\end{array}$ & $\begin{array}{l}2 \cdot 63 \\
2 \cdot 22 \\
2 \cdot 58\end{array}$ & $\begin{array}{l}4 \\
1 \\
-\end{array}$ & $\begin{array}{l}3 \cdot 20 \\
2 \cdot 25\end{array}$ \\
\hline & All & 16 & $2 \cdot 55$ & 5 & 3.01 \\
\hline \multirow[t]{2}{*}{$45-54$} & $\begin{array}{l}1 / 2,2 \text { or } 3 \\
A \\
B \text { or } C\end{array}$ & $\begin{array}{r}14 \\
15 \\
4\end{array}$ & $\begin{array}{l}2 \cdot 33 \\
2 \cdot 10 \\
1 \cdot 98\end{array}$ & $\begin{array}{l}5 \\
3 \\
2\end{array}$ & $\begin{array}{l}2 \cdot 47 \\
2 \cdot 05 \\
2 \cdot 35\end{array}$ \\
\hline & All & 33 & $2 \cdot 18$ & 10 & $2 \cdot 32$ \\
\hline \multirow[t]{2}{*}{$55-64$} & $\begin{array}{l}1 / 2,2 \text { or } 3 \\
A \\
B \text { or } C\end{array}$ & $\begin{array}{r}11 \\
12 \\
7\end{array}$ & $\begin{array}{l}1 \cdot 94 \\
1 \cdot 83 \\
2 \cdot 00\end{array}$ & $\frac{2}{2}$ & $\begin{array}{l}2 \cdot 25 \\
2 \cdot 15\end{array}$ \\
\hline & All & 30 & 1.91 & 4 & $2 \cdot 20$ \\
\hline \multirow[t]{2}{*}{ All } & $\begin{array}{l}1 / 2,2 \text { or } 3 \\
A \\
B \text { or } C\end{array}$ & $\begin{array}{l}36 \\
30 \\
13\end{array}$ & $\begin{array}{l}2 \cdot 30 \\
2 \cdot 01 \\
2 \cdot 08\end{array}$ & $\begin{array}{r}11 \\
4 \\
4\end{array}$ & $\begin{array}{l}2 \cdot 69 \\
2 \cdot 10 \\
2 \cdot 25\end{array}$ \\
\hline & All & 79 & $2 \cdot 15$ & 19 & $2 \cdot 48$ \\
\hline
\end{tabular}


TABLE 5

Summary of Smoking Habits of Categories $1 / 2$, 2, and 3 of Simple Pneumoconiosis AND PMF WHERE TyPe OF PNEUMOCONIOSIS WAS READ (Ages 35-64 YeARS)

\begin{tabular}{|c|c|c|c|c|c|}
\hline \multirow{2}{*}{$\begin{array}{l}\text { Type of simple } \\
\text { pneumoconiosis }\end{array}$} & \multirow[b]{2}{*}{ No. } & \multicolumn{4}{|c|}{ Smoking habits } \\
\hline & & Not known & Never smoked & Ex-smokers & Smokers \\
\hline $\begin{array}{l}\text { Micronodular or nodular } \\
\text { Punctiform }\end{array}$ & $\begin{array}{l}79 \\
19\end{array}$ & $\begin{array}{l}1 \\
1\end{array}$ & $\begin{array}{l}3 \\
1\end{array}$ & $\begin{array}{r}14 \\
3\end{array}$ & $\begin{array}{l}61 \\
14\end{array}$ \\
\hline
\end{tabular}

micronodular or nodular markings, $61(78 \%)$ were smokers and of the 18 men with punctiform markings, 14 (also $78 \%$ ) were smokers.

There is little information on the reproducibility of reading punctiform markings. It is therefore of interest that the films from this survey, along with two kinds of other films, those from asbestos workers and hard-metal workers, were recently read independently at the Medical Research Council's Pneumoconiosis Unit by Dr. J. C. Gilson (Oldham, personal communication). The agreement with the readings reported in this paper was 'exceedingly close' and only one of the simple pneumoconiosis films from the present series was read as having no small opacities. The readings by J.C.G. were in agreement in 14 of the cases of punctiform opacities, and in addition he read nine others. It seemed that, in general, J.C.G. accepted rather larger opacities as punctiform than one of us (A.L.C.) who read the films originally.

\section{Discussion}

Ryder et al. (1970) found that, among miners coming to necropsy, those who had shown a punctiform type of dust marking had a higher excess of emphysema compared with the micronodular and the nodular types. This finding occurred in both simple pneumoconiosis and in PMF. The impairment of the transfer factor found in miners with punctiform markings who attended a pneumoconiosis medical panel (Lyons et al., 1967) has been attributed to this emphysema. Jones, Burrows, and Fletcher (1967) have shown that the death rate in non-miners is related to the amount of emphysema. The 10-year follow-up of a random sample of miners and exminers presented here shows no evidence that those whose radiograph in 1958 was read as showing punctiform markings had a higher death rate. Indeed, there is a suggestion that the reverse may be the case. Also, there is the suggestion of better lung function, as estimated by the forced expiratory volume (Table 4). Incidentally, Table 4 suggests that category $\mathbf{A}$ is associated with reduced lung function compared with simple pneumoconiosis. The recent 20-year mortality study in the Rhondda Fach
(Cochrane, 1973) suggested that only categories B and $\mathbf{C}$ have much reduced survival rates. In view of the much larger numbers, and longer period of observation, greater credence should be given to the 20-year follow-up.

The present follow-up does not, therefore, support the hypothesis that punctiform opacities are associated with an excess of emphysema (which has a high mortality) compared with other types of pneumoconiosis. It should be noted that the proportion read as having punctiform opacities in this community study was about $20 \%$ of all those with pneumoconiosis in which type was read (Table 2) whereas in the study of Ryder et al. (1970), where all the cases were selected by death, the proportion with punctiform markings was higher (33 out of 109). The group in this present study are, therefore, a 'purer' sample of punctiform opacities ( $p / p$ rather than $p / m)$ and the independent reading of the radiographs by Dr. Gilson strengthens this conclusion. This group might therefore be expected to show any differences more strikingly.

The pneumoconiosis panel study (Lyons et al., 1967) of 47 subjects found that the proportion of smokers among those with punctiform opacities (13/16) was higher than among those with micronodular opacities. In the random sample described here we were unable to confirm this finding and, in fact, found that the percentage of smokers was similar in punctiform and micronodular and nodular types of pneumoconiosis (Table 5).

Gilson and Oldham (1970) have suggested, and give evidence, that the population studied at necropsy (Ryder et al., 1970) may show spurious relationships which do not exist in life. This may explain the apparent discrepancies between the results of this community survey and some of the necropsy data.

We wish to thank all those members of the Unit who helped in this survey. We are grateful to Dr. P. D. Oldham for the analysis of the independent reading of the radiographs and to Dr. J. E Cotes for helpful comments on early drafts of this paper.

\section{References}

Cochrane, A. L. (1973). Relation between radiographic 
categories of coalworkers' pneumoconiosis and expectation of life. British Medical Journal, 2, 532-534.

Cotes, J. E., Deivanayagam, C. M., Field, G. B., and Billiet, L. (1971) Relation between type of simple pneumoconiosis ( $P$ or $M$ ) and lung function. In Inhaled Particles: Proceedings of an International Symposium organised by the British Occupational Hygiene Society, London, Sept. 1970, Vol. 2, p. 633, edited by W. H. Walton. Unwin, London.

Davies, I., Fletcher, C. M., Mann, K. J., and Stewart, A. (1950). Radiological progression in coal-miners' pneumoconiosis. In Proceedings of the Ninth International Congress on Industrial Medicine, 1948, p. 773. Williams and Wilkins, Baltimore.

Fletcher, C. M. (1955). Classification of roentgenograms in pneumoconiosis. Archives of Industrial Health, 11, 17-28.

Gilson, J. C. and Oldham, P. D. (1970). Coalworkers' pneumoconiosis. British Medical Journal, 4, 305.

Higgins, I. T. T and Cochrane, A. L. (1961). Chronic respiratory disease in a random sample of men and women in the Rhondda Fach in 1958. British Journal of Industrial Medicine, 18, 93-102.

International Labour Office (1959). Meeting of experts on the international classification of radiographs of the pneumoconioses, Geneva, 1958. Occupational Safety and Health, 9, 63-69.
(1970) International Classification of Radiographs of Pneumoconiosis. Occupational Safety and Health Series No. 22. I.L.O., Geneva.

Jones, N. L., Burrows, B., and Fletcher, C. M. (1967). Serial studies of 100 patients with chronic airway obstruction in London and Chicago. Thorax, 22, 327-335.

Lapp, N. L. and Seaton, A. (1971). Pulmonary function. In Pulmonary Reactions to Coal Dust: A Review of U.S. Experience, edited by M. M. Key, L. E. Kerr, and M. Bundy. Academic Press, New York and London.

Lyons, J. P., Clarke, W. G., Hall, A. M., and Cotes, J. E. (1967). Transfer factor (diffusing capacity) for the lung in simple pneumoconiosis of coal workers. British Medical Journal, 4, 772-774.

Ryder, R., Lyons, J. P., Campbell, H., and Gough, J. (1970). Emphysema in coal workers' pneumoconiosis. British Medical Journal, 3, 481-487.

Received for publication 1 November 1973 